\title{
KARAKTERISTIK BUBUR BAYI INSTAN BERBAHAN DASAR TEPUNG BERAS MERAH DENGAN PENAMBAHAN EKSTRAK DAUN KELOR (MORINGA OLEIFERA LAM)
}

(Characteristics of instant baby breast based on red rice flour with addition of moringa leaf extract (Oleifera Lam)

\author{
Nilmawati Husain', Rosdiani Azis ${ }^{2}$, dan Adnan Engelen ${ }^{3}$ \\ 1,2,3 Progam Studi Teknologi Hasil Pertanian, Politeknik Gorontalo \\ *Email: rosdiani@poligon.ac.id ${ }^{2)}$
}

\begin{abstract}
ABSTRAK
Bubur bayi instan merupakan bubur yang memiliki komponen penyusun bubur bayi yang bersifat instan sehingga dalam penyajiannya tidak diperlukan proses pemasakan. Saat umur 6 bulan bayi membutuhkan makanan pendamping ASI (MP-ASI). Umumnya bubur bayi instan yang beredar di indonesia dibuat dengan bahan utama beras putih dan beras merah yang dikenal sebagai bahan pokok utama. Pada penelitian kali ini peneliti ingin bereksperimen dengan menambahkan beras merah dan ekstrak daun kelor. Penelitian ini bertujuan untuk mengetahui tingkat kesukaan bubur bayi instan dengan kombinasi tepung beras merah dengan penambahan ekstrak daun kelor, untuk mengetahui kandungan beberapa sifat kimia pada bubur instan. Metode yang digunakan pada tugas akhir ini adalah metode pengujian terhadap uji organoleptik, uji kadar air, uji kadar abu, viskositas, dan uji daya serap. Data yang diperlukan kemudian di uji dengan metode RAL dan dilanjutkan dengan uji BNT jika terdapat pengaruh yang nyata. Tahap-tahap dalam tugas akhir ini diantaranya dengan melakukan studi pustaka, pengumpulan data, dan analisa. Teknik pengujian yang digunakan uji organoleptik, uji kadar air, uji kadar abu, uji viskositas, dan uji daya serap. Hasil penelitian menunjukan hasil uji organoleptik memiliki tingkat kesukaan yang dihasilkan dari tiga perlakuan bubur bayi instan berbahan dasar tepung beras merah dan ekstrak daun kelor secara keseluruhan berada pada pada skala 5,61-6,92 atau dalam taraf biasa sampai sangat suka. Dan bubur bayi instan yang disukai oleh panelis atau masyarakat adalah perlakuan A1 bubur bayi instan berbahan dasar tepung beras merah dengan penambahan ekstrak daun kelor. Sedangkan pada Uji sifat kimia, perlakuan terbaik adalah perlakuan A3 yaitu dengan substitusi tepung beras merah $300 \mathrm{~g}$ dengan penambahan ekstrak daun kelor $90 \mathrm{~mL}$
\end{abstract}

Kata Kunci: Bubur instan; ekstrak; daun kelor; beras merah

\begin{abstract}
Instant baby porridge is a porridge that has instant baby porridge compiler components so that the cooking process is not required. At the age of 6 months, babies need complementary foods for ASI (MP-ASI). Generally, instant baby porridge circulating in Indonesia is made with the main ingredients of white rice and brown rice, which are known as the main staples. In this study, the researchers wanted to experiment with adding brown rice and Moringa leaf extract. This study aimed to determine the level of preference for instant baby porridge with a combination of red rice flour with the addition of Moringa leaf extract, to determine the content of some chemical properties in instant porridge. The method used in this thesis was a method of testing organoleptic tests, water content tests, ash content tests, viscosity, and absorbency tests. The data needed was then tested using the RAL method and continued with the LSD test if there was a real effect. The stages in this final project included conducting a literature study, data collection, and analysis. The testing technique used was an organoleptic test, water content
\end{abstract}


test, ash content test, viscosity test, and absorbency test. The results showed that the organoleptic test results had a preference level resulting from three treatments of instant baby porridge made from red rice flour and moringa leaf extract as a whole were on a scale of 5.616.92 or in the usual up to very high level. Instant baby porridge that was favored by panelists or the public was A1 treatment of instant baby porridge made from red rice flour with the addition of Moringa leaf extract. Whereas in the chemical properties test, the best treatment was A3 treatment with $300 \mathrm{~g}$ red rice flour substitution with the addition of $90 \mathrm{~mL}$ Moringa leaf extract.

Keywords: Instant porridg; extract; moringa leaf; red rice

\section{PENDAHULUAN}

Bubur bayi instan merupakan bubur yang memiliki komponen penyusun bubur bayi yang bersifat instan sehingga dalam penyajiannya tidak diperlukan proses pemasakan. Kebutuhan bayi akan zat gizi makin meningkat seiring dengan bertambahnya umur bayi sedangkan ASI kurang dapat mencukupi kebutuhan zat gizi bayi, sehingga bayi membutuhkan makanan pendamping ASI (MP-ASI). Umumnya bubur bayi instan yang beredar di Indonesia dibuat dengan bahan utama beras putih dan beras merah yang dikenal sebagai bahan pokok utama (Krisnatuti dan Yenrina, 2000).

Adapun bubur bayi yang ada saat ini mengandung pengawet buatan, hal ini sesuai pendapat Dr. Zulfito Marendra, dalam bukunya yang berjudul Menu Sehat \& Permainan Kreatif, dia menuliskan bahwa untuk meningkatkan kecerdasan anak makanan yang mengandung gula yang tinggi seperti: bubur, biskuit, dan sereal yang manis hampir tidak memiliki nilai gizi. Hal ini yang mendasari peneliti untuk melakukan penelitian pembuatan bubur instan yang alami tanpa adanya bahan pengawet, Adapun bahan yang digunakan adalah beras merah dan ekstrak daun kelor.

Beras merah adalah jenis beras yang dihasilkan dari padi dipanen dan kemudian dikeringkan untuk menghilangkan kadar airnya sampai mencapai minimal $14 \%$ dan diproses pecah kulit arinya. Selanjutnya kulit ari di beras merah mengandung zat yang sangat baik untuk perkembangan otak bayi bahkan kandungan mineral yang cukup tinggi memberikan manfaat untuk asupan kebutuhan nutrisi yang membantu menunjang pertumbuhan rambut, gigi, tulang dan otot bayi. Beras merah juga mengandung serat yang tinggi yang baik untuk pencernaan bayi dan juga kandungan zat besi untuk memenuhi kebutuhan asupan zat besi dalam pertumbuhan bayi. Masih kandungan beras merah, kandungan zat tamin yang terdapat pada beras merah sangat baik untuk perkembangan jaringan saraf dan jantung bayi. Bahkan kandungan fosfor yang terdapat di dalam beras merah akan membantu untuk perkembangan 
sistem saraf rangka bayi. Dengan mengkonsumsi beras merah maka bayi akan memiliki pola tidur yang cukup dikarenakan adanya kandungan zat tepung yang dapat meningkatkan serotonin dalam jaringan otak bayi. Serotonin memiliki peran dalam pengaturan tingkat kantuk sehingga lebih bisa teratur. Bahkan kandungan gula di dalam beras merah lebih stabil sehingga bayi tidak mudah lapar dan tidak menyebabkan bayi terbangun di malam hari karena rasa lapar yang menggangu tidurnya.

Tanaman kelor (Moringa oleifera) merupakan bahan makanan lokal yang memiliki potensi untuk dikembangkan dalam kuliner ibu menyusui, karena mengandung senyawa fitosterol yang berfungsi meningkatkan dan memperlancar produksi ASI (efek laktagogum). Daun kelor mengandung vitamin $\mathrm{A}$, vitamin $\mathrm{C}$, vitamin B6, kalsium, kalium, zat besi, dan protein. Pada penelitian kali ini peneliti ingin bereksperimen dengan menambahkan ekstrak daun kelor. Dengan adanya penjelasan diatas maka peneliti ingin memformulasikan ekstrak daun kelor dan beras merah untuk pembuatan bubur instan.

\section{METODE PENELITIAN}

Jenis penelitian yang dilakukan merupakan penelitian eksperimental dengan menggunakan Rancangan Acak Lengkap (RAL) dengan 3 perlakuan dan 3 ulangan sehingga memperoleh 9 satuan percobaan. Analisis ragam terhadap data hasil pengamatan dilakukan dengan uji $\mathrm{F}$, apabila menunjukkan pengaruh yang nyata maka dilakukan uji lanjut BNT.

\section{Prosedur pembuatan tepung beras merah (Wijayanti 2015)}

Beras merah di rendam pada wadah selama satu malam Beras merah kemudian di cuci bersih, beras dari air rendaman lalu di anginkan kemudian dikeringkan, Beras yang sudah dikeringkan kemudian dihaluskan dengan ginder. Di ayak dengan saringan 80 mesh. Di sangai hingga kering tapi jangan sampai merubah warna tepung beras, dengan api sedang. Di keringkan kembali di oven

\section{Proses pembuatan bubur instan} (Modifikasi Restiara dan Shanti 2016)

1. Pembuatan bubur bayi instan dilakukan dengan mencampur semua bahan sedikit demi sedikit sesuai dengan formulasi 100 gam tepung beras merah di tambah dengan ekstrak daun kelor. Dengan perbandingan sebagai berikut :

a) A1 tepung beras merah $300 \mathrm{~g}$ : ekstrak daun kelor $30 \mathrm{~mL}$

b) A2 tepung beras merah $300 \mathrm{~g}$ : ekstrak daun kelor $60 \mathrm{~mL}$

c) A3 tepung beras merah $300 \mathrm{~g}$ : ekstrak daun kelor $90 \mathrm{~mL}$

2. Campuran bahan ditambahkan air sebanyak $600 \mathrm{ml}$, lalu dimasak 
selama 10 menit dengan suhu $75^{\circ} \mathrm{C}$ hingga campuran bahan mengental

3. Bubur yang telah matang kemudian didinginkan selama 15 menit

4. Kemudian bubur dikeringkan didalam oven selama 3 jam dengan suhu $125^{\circ} \mathrm{C}$

5. Setelah kering, bubur dihaluskan dengan ginder

6. Bubur yang sudah halus tersebut lalu dikeringkan lagi didalam oven selama 15 menit dengan suhu $100^{\circ} \mathrm{C}$

7. Bubur yang sudah kering selanjutnya dihaluskan lagi dengan ginder dan diayak dengan ayakan 80 mesh

Adapun diagam alir pembuatan bubur bayi instan berbahan dasar tepung beras merah dengan penambahan ekstrak daun kelor sebagai berikut :

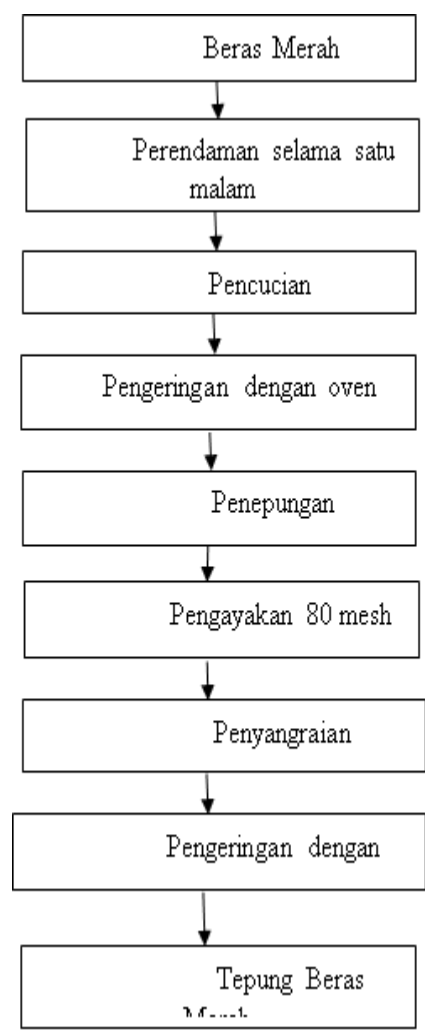

Gambar 1. Proses pembuatan tepung beras

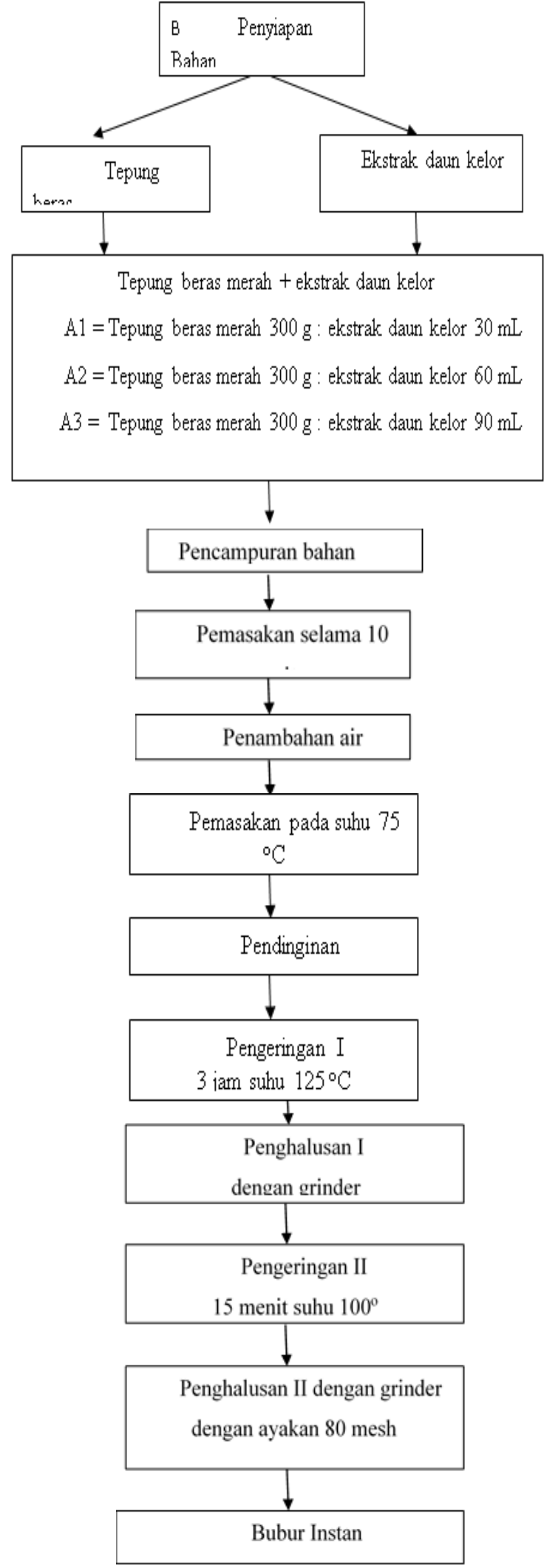

Gambar 2. Tahapan pembuatan bubur instan 


\section{HASIL DAN PEMBAHASAN}

\section{Warna}

Warna merupakan komponen yang sangat penting untuk menentukan kualitas atau derajat penerimaan suatu bahan pangan. Suatu bahan pangan meskipun dinilai enak dan teksturnya sangat baik, tetapi memiliki warna yang kurang sedap dipandang atau memberikan kesan menyimpang dari warna yang seharusnya, maka tidak layak dikonsumsi. Penentuan mutu suatu bahan pangan pada umumnya tergantung pada warna, karena warna tampil terlebih dahulu (Winarno, 2004).

Hasil uji organoleptik terhadap parameter warna bubur instan dengan penambahan tepung beras merah dan ekstrak daun kelor dapat dilihat pada gambar 3 berikut:

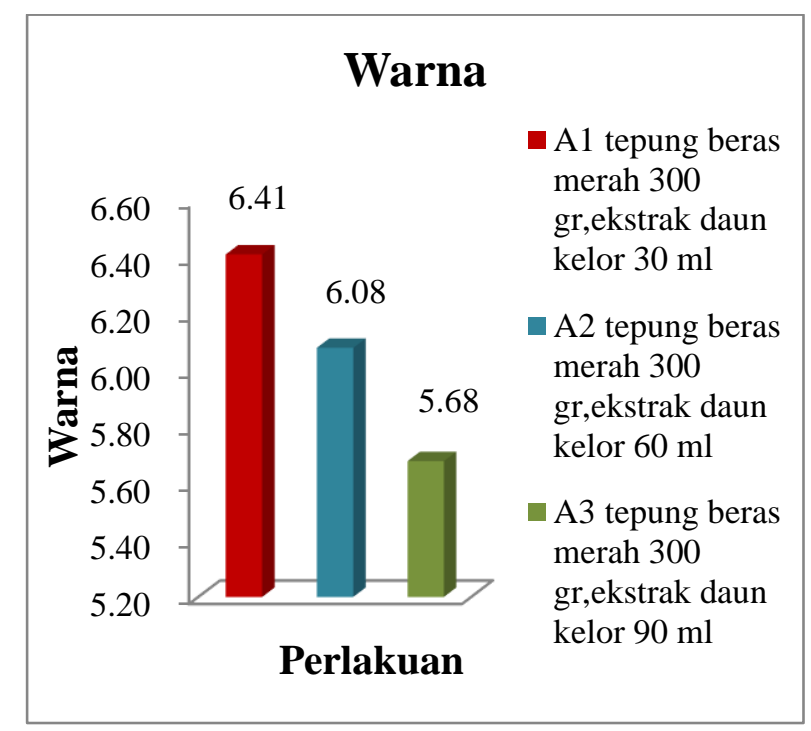

Gambar 3. Uji kesukaan warna bubur instan

Gambar 3 menunjukan bahwa tingkat penerimaan panelis terhadap parameter warna pada bubur instan berbahan dasar tepung beras merah dengan penambahan ekstrak daun kelor berkisar antara 5.68\% $6.41 \%$ atau berada dalam taraf agak suka sampai sangat suka. Nilai tertinggi terdapat pada perlakuan A1 yaitu dengan substitusi tepung beras merah $300 \mathrm{~g}$ dengan penambahan ekstrak daun kelor $30 \mathrm{~mL}$ dan nilai terendah terdapat pada perlakuan A3 yaitu dengan substitusi tepung beras merah $300 \mathrm{~g}$ dengan penambahan ekstrak daun kelor 90 mL. pada perlakuan A1, warna yang dihasilkan berwarna coklat muda, sedangkan pada perlakuan A3 menghasilkan warna coklat tua. Perbedaan warna yang dihasilkan pada perlakuan A1 dan A3 ini diduga akibat adanya penambahan ekstrak daun kelor yang berbeda. Semakin banyak penambahan ekstrak daun kelor, maka warna yang dihasilkan akan semakin tua.

\section{Aroma}

Aroma mempunyai peranan yang sangat penting dalam penentuan derajat penilaian dan kualitas suatu bahan pangan. Selain bentuk dan warna, bau atau aroma akan berpengaruh dan menjadi perhatian utama. Sesudah bau diterima maka penentuan selanjutnya adalah citarasa disamping teksturnya (Winarno, 2008). Hasil uji hedonik pada parameter aroma dapat dilihat pada gambar 4 berikut: 


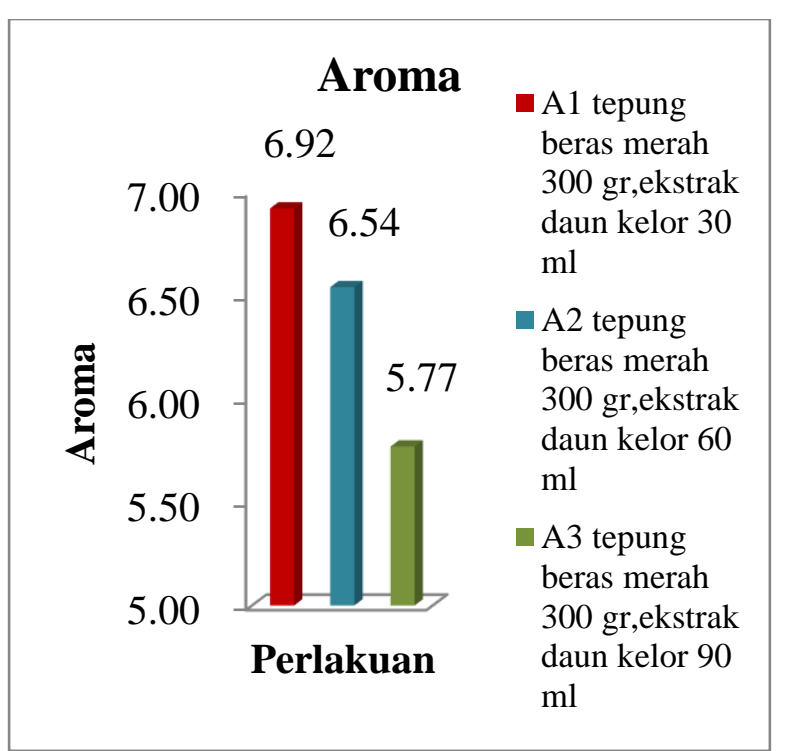

Gambar 4. Uji kesukaan aroma bubur instan

Gambar 4 menunjukan bahwa tingkat penerimaan panelis terhadap parameter aroma pada bubur instan berbahan dasar tepung beras merah dengan penambahan ekstrak daun kelor berkisar antara $5.77 \%-6.92 \%$ atau berada dalam taraf agak suka sampai sangat suka. Nilai tertinggi terdapat pada perlakuan A1 yaitu dengan substitusi tepung beras merah $300 \mathrm{~g}$ dengan penambahan ekstrak daun kelor 30 $\mathrm{mL}$ dan nilai terendah terdapat pada perlakuan A3 yaitu dengan substitusi tepung beras merah $300 \mathrm{~g}$ dengan penambahan ekstrak daun kelor $90 \mathrm{~mL}$. Hasil uji organoleptik menunjukan bahwa penambahan ekstrak daun kelor tidak menghasilkan perbedaan yang nyata terhadap aroma. Semua perlakuan menghasilkan aroma yang hampir sama. Pada perlakuan A3, aroma yang dihasilkan lebih rendah dari perlakuan A1 dan perlakuan A2, hal ini disebabkan karena pemberian ekstrak daun kelor yang semakin banyak, sehingga tidak begitu disukai oleh panelis.

\section{Rasa}

Rasa merupakan faktor yang paling penting dalam menentukan keputusan bagi konsumen untuk menerima atau menolak suatu produk pangan. Meskipun, parameter lain nilainya baik, jika rasa tidak enak atau tidak disukai maka produk akan ditolak. Ada empat jenis rasa dasar yang dikenali oleh manusia yaitu asin, asam, manis dan pahit (Soekarto, 2013). Produk bubur bayi instan dari tepung beras merah dan ekstrak daun kelor merupakan produk pangan yang memiliki rasa agak manis meskipun tidak digunakan gula sebagai bahan tambahannya. Hasil uji hedonik terhadap parameter rasa dapat dilihat pada Gambar 5 berikut:

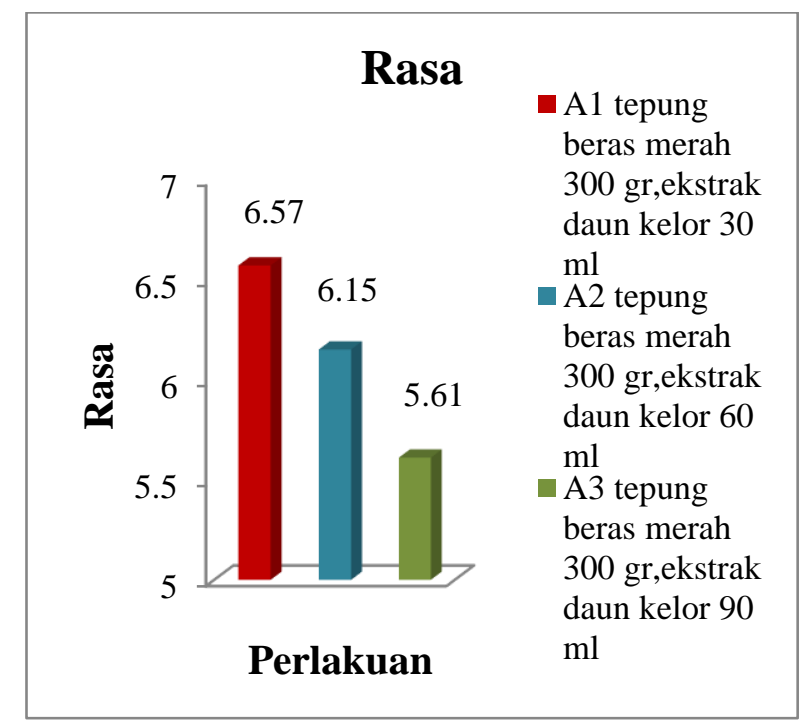

Gambar 5. Uji kesukaan rasa bubur instan 
Gambar 5 menunjukan bahwa tingkat penerimaan panelis terhadap parameter Rasa pada bubur instan berbahan dasar tepung beras merah dengan penambahan ekstrak daun kelor berkisar antara $5.61 \%-6.57 \%$ atau berada dalam taraf netral sampai sangat suka. Nilai tertinggi terdapat pada perlakuan A1 yaitu dengan substitusi tepung beras merah $300 \mathrm{~g}$ dengan penambahan ekstrak daun kelor 30 $\mathrm{mL}$ dan nilai terendah terdapat pada perlakuan A3 yaitu dengan substitusi tepung beras merah $300 \mathrm{~g}$ dengan penambahan ekstrak daun kelor $90 \mathrm{~mL}$. Hasil uji organoleptik menunjukan bahwa penambahan ekstrak daun kelor tidak menghasilkan perbedaan yang nyata terhadap rasa. Pada perlakuan A3, nilai rasa yang dihasilkan lebih rendah dari perlakuan A1 dan perlakuan A2, hal ini disebabkan karena pemberian ekstrak daun kelor yang semakin banyak dan berlebihan sehingga tidak terlalu disukai oleh panelis.

\section{Tekstur}

Setiap makanan mempunyai sifat tekstur tersendiri tergantung keadaan fisik, ukuran dan bentuknya. Penilaian terhadap tekstur dapat berupa kekerasan, kelembutan, elastisitas, kerenyahan, kelengketan, dan sebagainya. Tekstur merupakan penentu terbesar mutu rasa Dewi Kusuma, (2008). Tekstur produk pangan merupakan salah satu komponen yang dinilai dalam uji organoleptik.
Hasil uji hedonik terhadap parameter tekstur dapat dilihat pada Gambar 6 berikut:

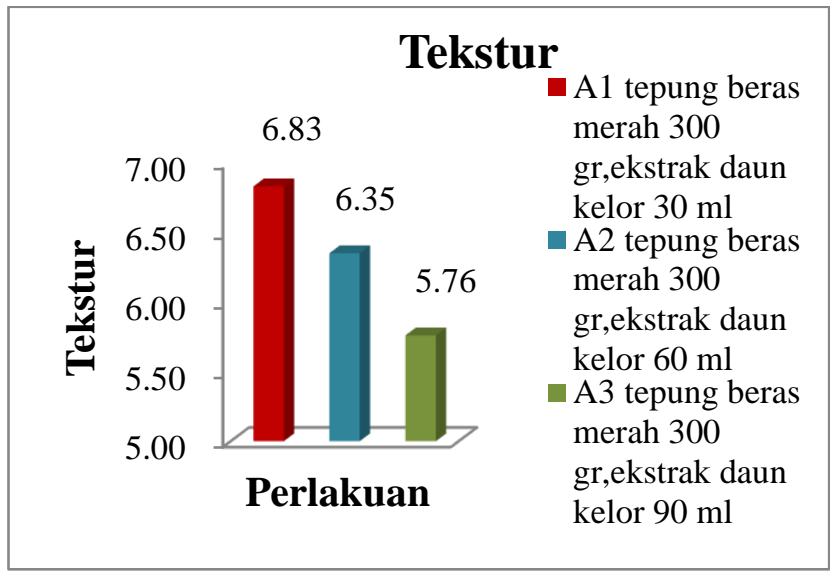

Gambar 6. Uji kesukaan tekstur bubur instan

Gambar 6 menunjukan bahwa tingkat penerimaan panelis terhadap parameter tekstur pada bubur instan berbahan dasar tepung beras merah dengan penambahan ekstrak daun kelor berkisar antara 5.76\% $6.83 \%$ atau berada dalam taraf agak suka sampai sangat suka. Nilai tertinggi terdapat pada perlakuan A1 yaitu dengan substitusi tepung beras merah $300 \mathrm{~g}$ dengan penambahan ekstrak daun kelor $30 \mathrm{~mL}$ dan nilai terendah terdapat pada perlakuan A3 yaitu dengan substitusi tepung beras merah $300 \mathrm{~g}$ dengan penambahan ekstrak daun kelor $90 \mathrm{~mL}$. Hasil uji organoleptik menunjukan bahwa penambahan ekstrak daun kelor tidak menghasilkan perbedaan yang nyata terhadap tekstur. Semua perlakuan menghasilkan tekstur yang hampir sama. Pada perlakuan A3, tekstur yang dihasilkan lebih rendah dari perlakuan A1 dan perlakuan A2, hal ini disebabkan 
karena pemberian ekstrak daun kelor yang semakin banyak, sehingga teksturnya agak kasar berbeda dengan perlakuan A1 dan A2 yang teksturnya agak lembut dan halus.

\section{Analisis Sifat Kimial}

\section{Kadar Air}

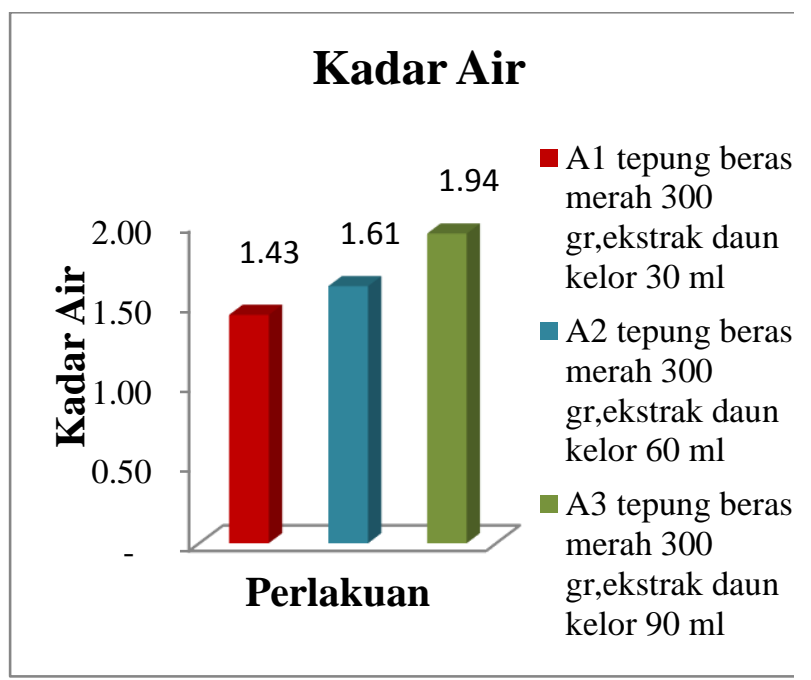

Gambar 7. Hasil pengujian kadar air pada beberapa perlakuan

Hasil analisis rata-rata kadar air pada bubur instan dengan penambahan tepung beras merah dan ekstrak daun kelor dari tiga perlakuan dengan tiga kali ulangan analisis dengan hasil rata-rata disajikan pada gambar berikut: Berdasarkan gambar 9 dapat dilihat bahwa nilai rata-rata kadar air bubur instan dengan penambahan tepung beras merah dan ekstrak daun kelor dari tiga perlakuan dengan tiga kali ulangan berkisar antara $1.43 \%-1.94 \%$. Tingginya kadar air pada perlakuan A3 menggunakan ekstrak daun kelor sebesar $90 \mathrm{~mL}$ berbanding dengan perlakuan A2 dengan menggunakan ekstrak daun kelor sebesar $60 \mathrm{~mL}$ dan A1 yang menggunakan ekstrak daun kelor sebesar $30 \mathrm{~mL}$. Kadar air tertinggi terdapat pada perlakuan A3 yaitu dengan penambahan ekstrak daun kelor sebesar $90 \mathrm{~mL}$. Tingginya kadar air tersebut dikarenakan pada perlakuan A3 menggunakan ekstrak daun kelor yang lebih banyak dari perlakuan A1 dan perlakuan A2. Hal ini disebabkan karena ekstrak daun kelor yang diberikan merupakan ekstrak daun kelor dalam bentuk cair, Sehigga kadar air yang dihasilkan pada perlakuan A3 lebih tinggi dari perlakuan A1 dan A2. Jadi dapat disimpulkan bahwa semakin banyak ekstrak daun kelor, maka kadar air yang dihasilkan juga akan semakin tinggi. Hal ini sesuai dengan pendapat Winarno (2004) menyatakan bahwa semakin tinggi kandungan air suatu bahan maka tingkat kerusakannya semakin cepat dan semakin rendah kadar air suatu bahan maka semakin lambat tingkat kerusakan itu sendiri.

Hasil analisis sidik ragam, diperoleh bahwa nilai $F_{\text {hitung }} 5.25$ lebih kecil dari $F_{\text {tabel }}$ (0.05) yaitu 5.14 dan $F_{\text {tabel }}(0.01)$ yaitu 10.92, artinya bahwa perlakuan pada pembuatan bubur instan dengan penambahan tepung beras merah dan ekstrak daun kelor tidak berbeda nyata terhadap kadar air yang diperoleh, sehingga dilakukan uji lanjut BNT. Hasil uji lanjut BNT disajikan pada tabel 1 berikut : Tabel 1 Nilai rata-rata kadar air pada bubur instan 
dari tepung beras merah dan ekstrak daun kelor.

\begin{tabular}{ll}
\hline Kode Perlakuan & Rata-rata \\
\hline A1 & $1.43 \mathrm{a}$ \\
A2 & $1.61 \mathrm{~b}$ \\
A3 & $1.94 \mathrm{c}$ \\
\hline
\end{tabular}

Berdasarkan tabel 1 hasil uji lanjut BNT menunjukan bahwa perlakuan A1 yang menggunakan ekstrak daun kelor sebesar $30 \mathrm{ml}$ berbeda nyata dengan perlakuan A2 yang menggunakan ekstrak daun kelor sebesar $60 \mathrm{ml}$. Sedangkan perlakuan A2 yang menggunakan ekstrak daun kelor sebesar $60 \mathrm{ml}$ sangat berbeda nyata dengan perlakuan A3 yang menggunakan ekstrak daun kelor sebesar $90 \mathrm{~mL}$.

\subsubsection{Kadar Abu}

Hasil analisis rata-rata kadar abu pada bubur instan dengan penambahan tepung beras merah dan ekstrak daun kelor dari tiga perlakuan dengan tiga kali ulangan analisis dengan hasil rata-rata disajikan pada gambar 8 berikut:

\section{Kadar abu}

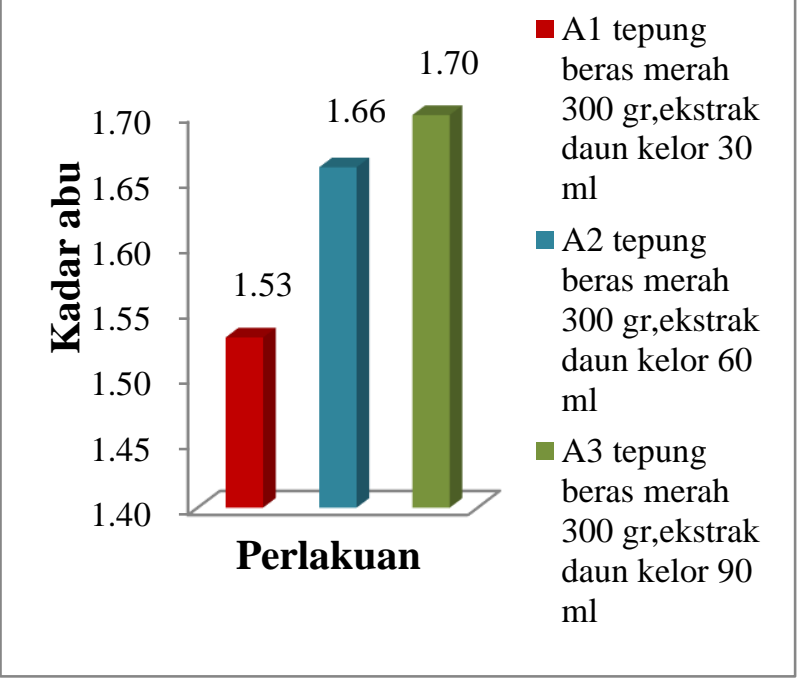

Gambar 8. Hasil pengujian kadar abu pada beberapa perlakuan

Berdasarkan gambar 8 dapat dilihat bahwa nilai rata-rata kadar abu bubur instan dengan penambahan tepung beras merah dan ekstrak daun kelor dari tiga perlakuan dengan tiga kali ulangan berkisar antara $1.53 \%-1.70 \%$. Tingginya kadar abu pada perlakuan A3 menggunakan ekstrak daun kelor sebesar $90 \mathrm{~mL}$ berbanding dengan perlakuan A2 dengan menggunakan ekstrak daun kelor sebesar $60 \mathrm{~mL}$ dan A1 yang menggunakan ekstrak daun kelor sebesar $30 \mathrm{~mL}$. Kadar abu tertinggi terdapat pada perlakuan A3 yaitu dengan penambahan ekstrak daun kelor sebesar $90 \mathrm{~mL}$. Tingginya kadar abu tersebut dikarenakan pada perlakuan A3 menggunakan ekstrak daun kelor yang lebih banyak dari perlakuan A1 dan perlakuan A2. Sehingga pada perlakuan A3, kadar abu yang dihasilkan lebih tinggi perlakuan A1 dan 
A2. Hal ini diduga karena kandungan mineral yang terkandung pada perlakuan A3 lebih banyak dari perlakuan A1 dan A2, sehigga dapat disimpulkan bahwa semakin banyak ekstrak daun kelor yang digunakan maka kadar abu yang dihasilkan juga akan semakin tinggi. Hal ini sesuai dengan pendapat Winarno (2002) yang menyatakan bahwa semakin tinggi kadar abu suatu produk maka semakin tinggi pula kandungan mineral pada produk tersebut.

Hasil analisis sidik ragam, diperoleh bahwa nilai $F_{\text {hitung }} 0.62$ lebih kecil dari $\mathrm{F}_{\text {tabel }}$ (0.05) yaitu 5.14 dan $F_{\text {tabel }}(0.01)$ yaitu 10.92, artinya bahwa perlakuan pada pembuatan bubur instan dengan penambahan tepung beras merah dan ekstrak daun kelor tidak berbeda nyata terhadap kadar abu yang diperoleh.

\section{Viskositas}

Viskositas tepung merupakan suatu keadaan yang menunjukan ganula pati dalam suatu larutan yang menyebabkan larutan tersebut mengalami kekentalan. Menurut Tester and Karkalas (1996), yang menyatakan bahwa viskositas disebabkan terjadinya pembengkakan maksimum, dan ganula pati pecah, kemudian pemanasan tetap dilanjutkan, maka akan terjadi penurunan viskositas akibat proses degadasi molekul pati (amilosa dan amilopektin) dalam kondisi demikian kemampuan mengikat air juga melemah. Semakin sedikit jumlah gugus hidroksil dari molekul pati semakin kecil kemampuannya menyerap air, oleh karena itu absorbsi air sangat berpengaruh terhadap viskositasnya.

Hasil analisis rata-rata viskositas pada bubur instan dengan penambahan tepung beras merah dan ekstrak daun kelor dari tiga perlakuan dengan tiga kali ulangan analisis dengan hasil rata-rata disajikan pada gambar 9 berikut:

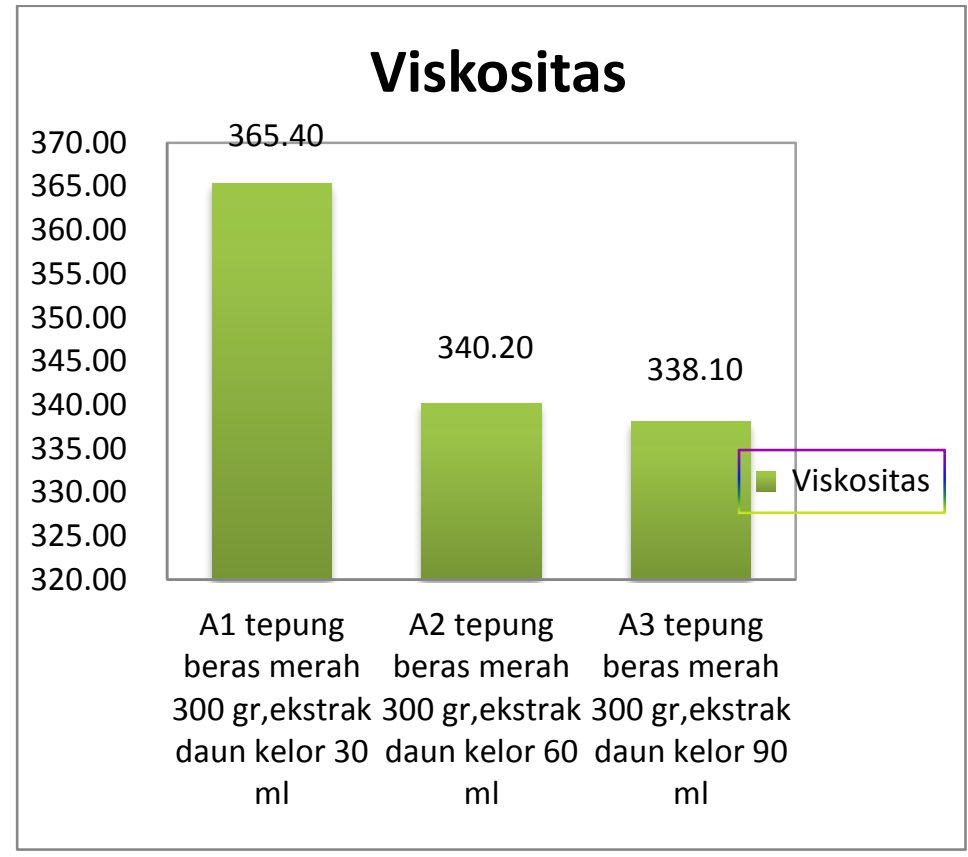

Gambar 9. Hasil pengujian kadar abu pada beberapa perlakuan

Hasil analisa viskositas bubur bayi instan menggunakan viscometer pada Gambar 9, menunjukkan viskositas bubur bayi instan yang paling tinggi yaitu pada perlakuan A1 yaitu sebesar $3365.40 \mathrm{cp}$ dan yang paling rendah yaitu pada perlakuan A3 yaitu sebesar 338.10 cp. Viskositas bubur bayi instan dipengaruhi oleh jumlah tepung yang terkandung didalam suatu 
bahan pangan, dimana kandungan tepung berbanding lurus dengan viskositas. Hal ini sesuai dengan pendapat Anggaini (2008), yang menyatakan sifat fungsional tepung yang penting adalah kemampuan untuk mengentalkan dan membentuk gel. Sifat pengental tepung ditunjukkan dengan kemampuan tepung mencapai viskositas tinggi selama pemanasan. Jika dilihat dari hasil penelitian perlakuan A1 yang menggunakan daun kelor sebesar $30 \mathrm{ml}$ lebih besar dibandingkan dengan perlakuan A2 yang menggunakan daun kelor sebesar $60 \mathrm{ml}$ dan A3 yang menggunakan daun kelor sebesar $90 \mathrm{ml}$. Hal ini disebabkan karena viskositas suatu bahan pangan bukan hanya dipengaruhi oleh kandungan tepung tetapi ada beberapa faktor seperti suhu, kosentrasi, larutan, tekanan dan ekstrak daun kelor. Hal ini sesuai dengan pendapat Towle (1973), yang menyatakan bahwa viskositas adalah derajat kekentalan suatu produk pangan.

\section{Daya Serap}

Daya serap air merupakan sifat fisik yang dipertimbangkan untuk makanan bayi, dinyatakan sebagai banyaknya air yang diserap oleh tiap gam bahan. Menurut Zayas (1997) daya serap air adalah kemampuan untuk mengikat air yang ada dalam bahan maupun yang ditambahkan selama proses. Daya serap air merupakan parameter yang menunjukkan besarnya kemampuan bahan menarik air disekelilingnya untuk berikatan dengan partikel bahan atau bertahan pada pori antar partikel bahan.

Hasil analisis rata-rata viskositas pada bubur instan dengan penambahan tepung beras merah dan ekstrak daun kelor dari tiga perlakuan dengan tiga kali ulangan analisis dengan hasil rata-rata disajikan pada gambar 10 berikut:

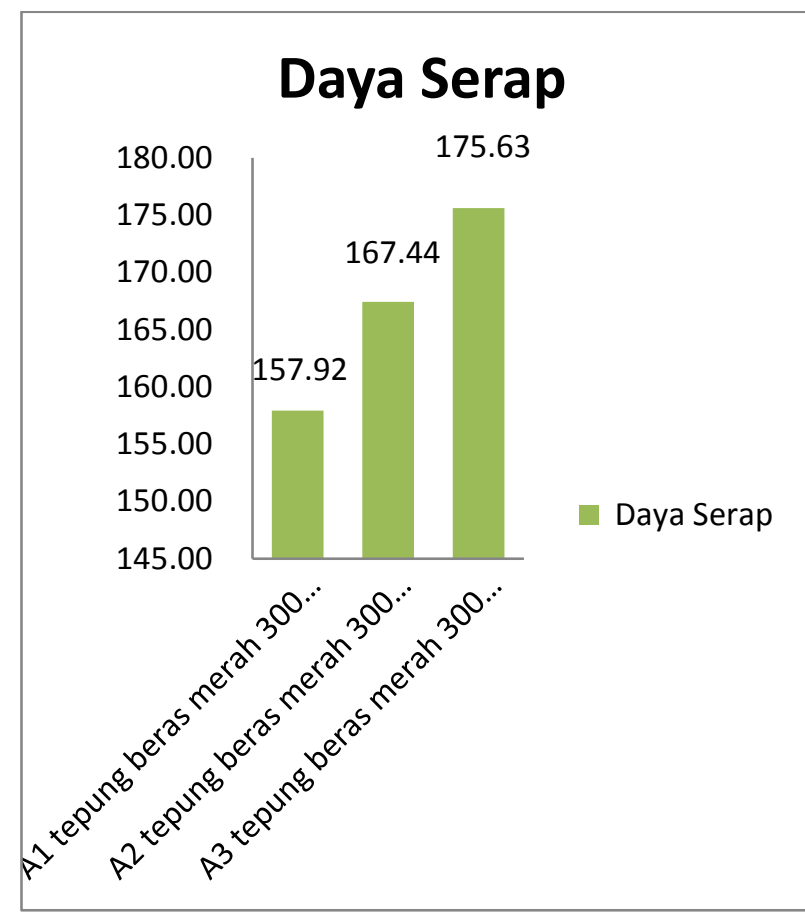

Gambar 10. Hasil pengujian daya serap.

Hasil analisa daya serap bubur bayi instan pada Gambar 10, menunjukkan daya serap bubur bayi instan yang paling tinggi yaitu pada perlakuan A3 yang menggunakan daun kelor sebanyak $90 \mathrm{ml}$, yaitu sebesar $175.63 \%$ dan yang paling rendah yaitu pada perlakuan A1 yang menggunakan daun kelor sebanyak $30 \mathrm{ml}$ sebesar $157.92 \%$ Hasil daya serap dipengaruhi oleh kandungan tepung dan 
protein yang terkandung pada tepung beras merah dan ekstrak daun kelor. Pada pengujian daya serap ini dipengaruhi oleh penambahan ekstrak daun kelor, semakin banyak penambahan ekstrak daun kelor maka semakin tinggi pula daya serap air pada bubur bayi. Hal ini dikarenakan ekstrak daun kelor memiliki kandungan protein yang tinggi dimana jika kandungan protein yang tinggi maka ia akan bersifat hidrofilik akan lebih mudah menyerap air. Hal ini sesuai dengan pendapat Alsuhendra dan Ridawati (2009) yang menyatakan bahwa daya serap air dipengaruhi oleh kandungan karbohidrat, baik tepung atapun serat kasar, serta protein dan komponen lainnya yang bersifat hidrofilik. Hal ini sesuai dengan daya serap air produk MPASI komersial adalah 3,60 - 46 6,20 g/g. Daya serap air juga berkaitan dengan sifat kelarutan tepung saat ditambahkan air. Pada makanan bayi, daya serap air yang lebih rendah adalah yang diharapkan. Sifat menyerap banyak air atau daya serap air yang tinggi dapat membuat bahan menjadi kamba dan mudah menjadi kental bila dipanaskan. Hal ini penting diperhatikan, karena volume lambung bayi relatif sangat kecil, sehingga belum cukup banyak mengkonsumsi makanan sapihan lambungnya sudah penuh dan bayi merasa kenyang.

\section{KESIMPULAN}

Berdasarkan penelitian yang telah dilakukan dapat disimpulkan bahwa Pada uji organoleptik, perlakuan A1 (tepung beras merah $300 \mathrm{~g}$ dengan penambahan ekstrak daun kelor $30 \mathrm{ml}$ ) mendapatkan nilai terbaik dari 4 parameter, yaitu parameter warna, aroma, rasa dan tekstur. Sedangkan pada Uji sifat kimia, perlakuan terbaik adalah perlakuan A3 yaitu dengan substitusi tepung beras merah $300 \mathrm{~g}$ dengan penambahan ekstrak daun kelor $90 \mathrm{ml}$.

\section{DAFTAR PUSTAKA}

Alsuhendra dan Ridawati. 2009. Pengaruh modifikasi secara pregelatinisasi, asam, dan enzimatis terhadap sifat fungsional tepung umbi gembili (Dioscorea esculenta). PS tata boga jurusan IKK UNJ Kampus UNJ Rawamangun.

Anggaini, F 2008. Hubungan antara gaya hidup dengan status kesehatan lansia binaan puskesmas pekayon jaya bekasi tahun 2008, Skripsi. Fakultas kedokteran Universitas Indonesia.

Kusuma D, S.2008. Pembuatan produk nasi singkong instan berbasis Fermented cassava flour sebagai bahan pangan pokok alternatif. Skripsi. Departemen ilmu dan teknologi pangan. Fakultas teknologi pertanian. IPB, Bogor.

Soekarto. 2013. Rasa makanan dan cara menikmati. Bharata Daya Aksara.

Tester, R.F. dan Karkalas, J. 1996. Swelling and gelatinization of oat starches. Cereal chemistry, 73:271-273 
Wijayanti. I. 2015. Eksperimen pembuatan kue semprit tepung beras merah. Skripsi Fakultas Teknik Universitas Negeri Semarang, Semarang.

Winarno, F.G. 2004. Kimia pangan dan gizi. Gramedia Pustaka Utama. Jakarta.

Winarno, F.G. 2008. Kimia pangan dan gizi. M-Brio Press, Bogor.

Winarno, F.G., 2002. Bahan tambahan makanan. Gramedia Pustaka Utama. Jakarta. 